\title{
Water's Journey Through Natural and Human Systems ${ }^{1}$
}

\section{Gabriela Sullivan and Martha Monroe ${ }^{2}$}

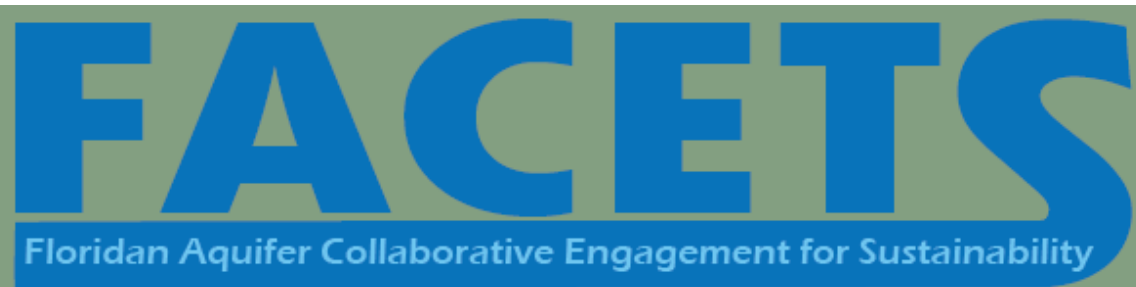

Residents, farmers, and businesses in southwestern Georgia and northern and central Florida depend on the groundwater from the Floridan Aquifer. The availability of this clean water is important for natural ecosystems, agriculture, the economy, tourists, and the people who call Florida and Georgia home. This factsheet will provide an overview of the Floridan Aquifer and how water from the Floridan Aquifer cycles through natural and human systems.

\section{The Floridan Aquifer}

The Floridan Aquifer is a natural underground water reservoir spanning 100,000 square miles and supplying 10 million people with drinking water (USGS n.d.). It collects, stores, and transports groundwater in vast underground tracts of limestone riddled with countless small pores and cracks that allow water to travel through it. The limestone forming the Floridan Aquifer extends below southern Georgia, all of Florida, and parts of South Carolina and Alabama (St. Johns River Water Management District n.d.). The geologic structure of the Floridan Aquifer varies across these states; however, this publication focuses on the Floridan Aquifer in southwestern Georgia and northern and central Florida because the geology of much of this region makes the aquifer especially susceptible to contamination from the surface above.
If you were to slice into Florida and southern Georgia like a piece of cake, you would see distinct layers of rock formed over millions of years (Figure 1). In many areas, the Floridan Aquifer is split into two layers: the upper and lower aquifer. The lower Floridan Aquifer is separated from the upper Floridan Aquifer by a layer of impermeable material known as a confining layer. The thickness and depth of the upper and lower aquifers vary across the region the aquifer supplies. Most water extracted for human use comes from the upper aquifer. The upper-aquifer water is of higher quality and closer to the surface and thus more accessible.

A majority of the upper Floridan Aquifer is confined or thinly confined, which means it is covered with impermeable clay and sediment, which prevents rainwater and other liquids from seeping through the ground (Figure 2). However, in parts of southern Georgia and northern and central Florida, the aquifer is unconfined. The surface of the unconfined aquifer is permeable sediment that easily permits rainwater to flow through to the aquifer below. Water isn't always the only thing that flows into the aquifer. In unconfined regions, contaminants can seep into the aquifer when it rains. The contaminants can pollute the aquifer and in turn affect the water that is extracted from the aquifer.

1. This document is FOR374, one of a series of the School of Forest, Fisheries, and Geomatics Sciences. Original publication date December 2021. Visit the EDIS website at https://edis.ifas.ufl.edu for the currently supported version of this publication.

2. Gabriela Sullivan, student assistant; and Martha Monroe, professor and associate director, School of Forest, Fisheries, and Geomatics Sciences, UF/IFAS Extension, Gainesville, FL 32611.

The Institute of Food and Agricultural Sciences (IFAS) is an Equal Opportunity Institution authorized to provide research, educational information and other services

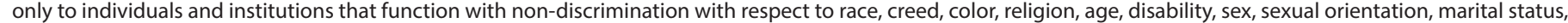

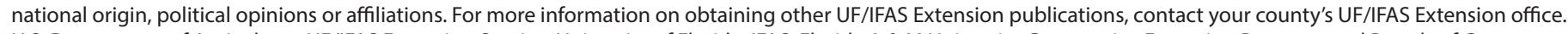
U.S. Department of Agriculture, UF/IFAS Extension Service, University of Florida, IFAS, Florida A \& M University Cooperative Extension Program, and Boards of County Commissioners Cooperating. Nick T. Place, dean for UF/IFAS Extension. 


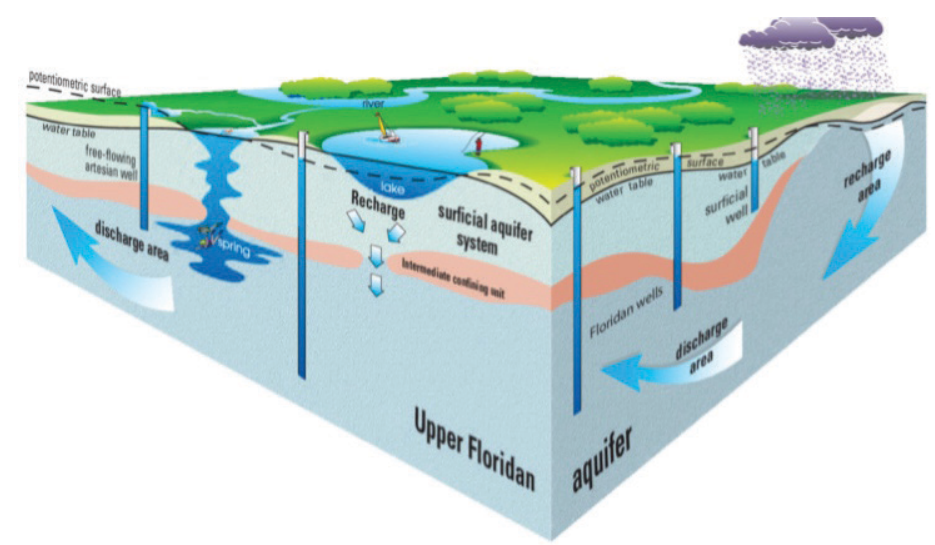

Figure 1. Conceptual drawing by St. Johns Water Management District, as featured in: Lee, T.M., \& Fouad, G.G. (2014). Creating a monthly time series of the potentiometric surface in the Upper Floridan aquifer, Northern Tampa Bay area, Florida, January 2000-December 2009. Scientific Investigations Report.

Credits: USGS https://pubs.usgs.gov/circ/2005/1278/pdf/cir1278.pdf

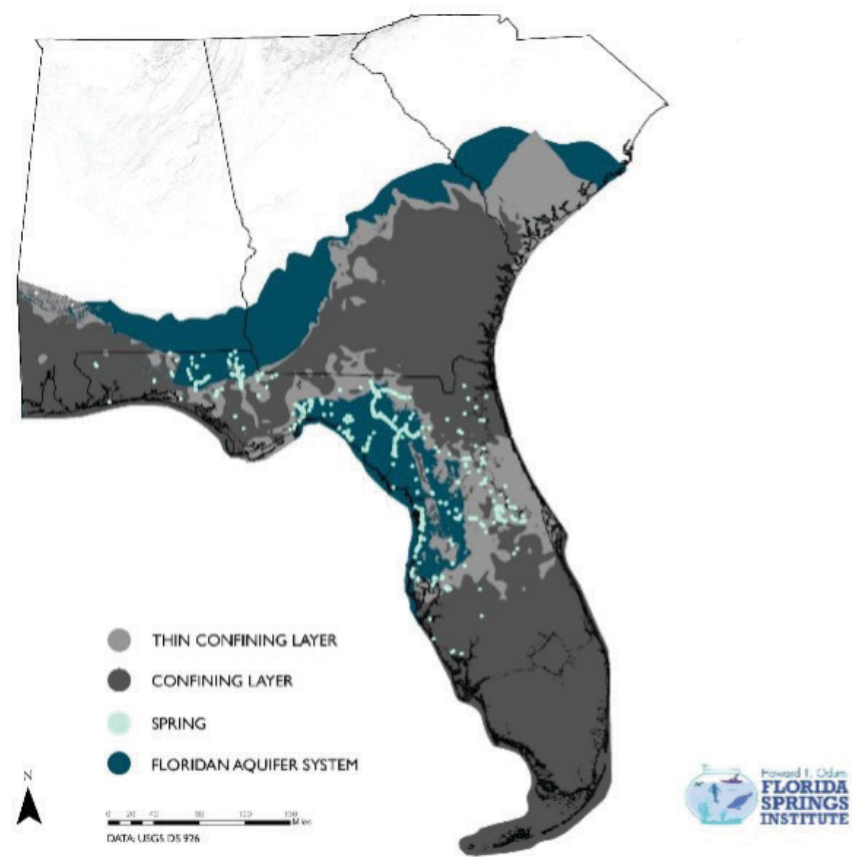

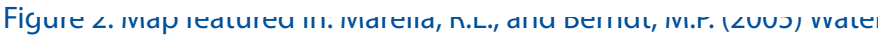
withdrawals and trends from the Floridan aquifer system in the southeastern United States, 1950-2000: U.S. Geological Survey Circular 1278.

Credits: USGS https://pubs.usgs.gov/circ/2005/1278/pdf/cir1278.pdf

\section{The Floridan Aquifer and Human- Engineered Systems}

Water's journey through natural and human-engineered systems is complex and often not linear. This publication will simplify water's journey from the Floridan Aquifer through rural and urban human-engineered systems. The following sections will elaborate on where the water you use every day to brush your teeth and flush the toilet comes from and where it goes after leaving your home.

\section{Rainfall}

Rain is the main source of water for the Floridan Aquifer. After it rains, rainwater seeps into the ground and eventually makes its way into the aquifer. On average, only $25 \%$ of rainfall in Florida ends up in the aquifer (St. Johns River Water Management District n.d.). Most rainwater travels across the landscape into lakes, streams, or rivers, or it evaporates back into the atmosphere. The Floridan Aquifer relies on rainfall to refill the aquifer as water is pumped out for municipal and agricultural use, or escapes from the aquifer to feed the springs, rivers, and streams (Borisova and Wade 2017).

\section{Water Extraction and Treatment}

Freshwater is extracted from the ground for use in industries, businesses, and in people's homes and on their landscaping. In southern Georgia and north and central Florida, wells pump groundwater from the underlying aquifers (Figure 3). Residents who receive their water from their local municipality rely on public supply wells which pump water from the upper Floridan Aquifer. The public water supply is treated at a water treatment facility before it reaches a resident's house. The water treatment process starts by adding chlorine to the extracted water to remove the hydrogen sulfide (GRU n.d.). Next, lime is added to soften the water. The water's $\mathrm{pH}$ is lowered with carbon dioxide (GRU n.d.). In addition, fluoride is added, and the water is filtered (GRU n.d.). Once filtered, chlorine is once again added to kill any remaining bacteria (GRU n.d.) Municipalities are required to monitor drinking water quality and meet the standards set forth by the Environmental Protection Agency.

Domestic (private) wells pump water from the upper aquifer directly into businesses and residential homes that do not receive water from public water systems. These businesses and homeowners are responsible for monitoring the quality of the water pumped from the ground. The Florida Department of Health strongly recommends testing water from private wells for water for bacteria and nitrate at least annually. In addition, agricultural wells pump water for irrigation. Half of the water withdrawn from the Floridan Aquifer supplies industries and agriculture (USGS n.d.).

\section{Water Transportation and Use}

In municipalities, treated water is stored in large reservoirs and water towers to ensure that water is available to residents and businesses at all times. Treated water flows through underground pipes to businesses, industries, and residential homes. Once water is used, it is considered wastewater. 


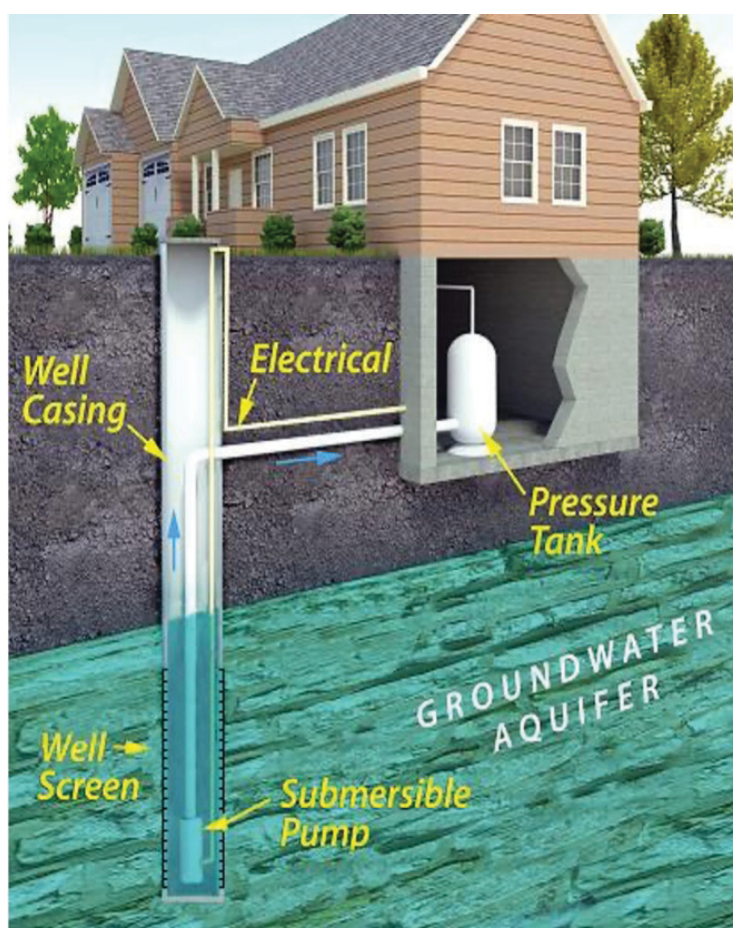

Figure 3. Conceptual drawing by U.S. Environmental Protection Agency, as featured in: United States Geological Society. (USGS). Credits: USGS https://www.usgs.gov/special-topic/water-scienceschool/science/groundwater-wells?qt-science_center_objects=0\#qtscience_center_objects

\section{Wastewater Treatment}

Before water is reused by people or released in the environment, it must meet standards outlined in the federal and state regulations. Generally, water undergoes a two-step treatment process to meet the requirements. In many urban areas, water that is used by industries and businesses and in homes is collected in underground pipes and transported to a wastewater treatment facility. Most water undergoes a two-step treatment process at the wastewater facility to meet the requirements, and some communities add a third element of natural treatment, such as a wetland.

Primary: The wastewater starts off by traveling through a screen which removes large objects like sticks (US EPA 1998). As the wastewater makes its way through several chambers and tanks, large particles suspended in the water slowly sink to the bottom on the tanks before the water moves to next step (US EPA 1998).

Secondary: Microorganisms are added to the wastewater to consume pathogens and organic material. An aeration tank adds oxygen to the bacteria mixture (US EPA 1998). Chlorine is added to kill any bacteria that may remain in wastewater (US EPA 1998).
Often, businesses and residential homes on well water use onsite sewage treatment mechanisms known as septic systems to treat and dispose of wastewater. Septic systems are designed to collect, treat, and dispose of wastewater. There are many different types of septic systems. A conventional septic system consists of a septic tank and a drain field (Figure 4). The septic tank collects the wastewater from the business or home. In the tank, gravity separates the wastewater into sludge, liquid wastewater (effluent), and scum (Toor et al. 2011). Sludge is the solid waste that settles at the bottom of the tank, while scum includes the oils and fats that float to the top of the tank (Toor et al. 2011). The remaining wastewater in between is effluent. Anaerobic bacteria pretreat the wastewater in the tank (Toor et al. 2011). The sludge and scum remain in the tank, while the effluent flows through the tank to the drain field. A drain field is a plot of land with unsaturated soil. Pipes with holes on the bottom are connected to the septic tank and traverse the drain field releasing effluent into the ground. Through natural processes, the soil treats the effluent as it seeps through the layers of soil.

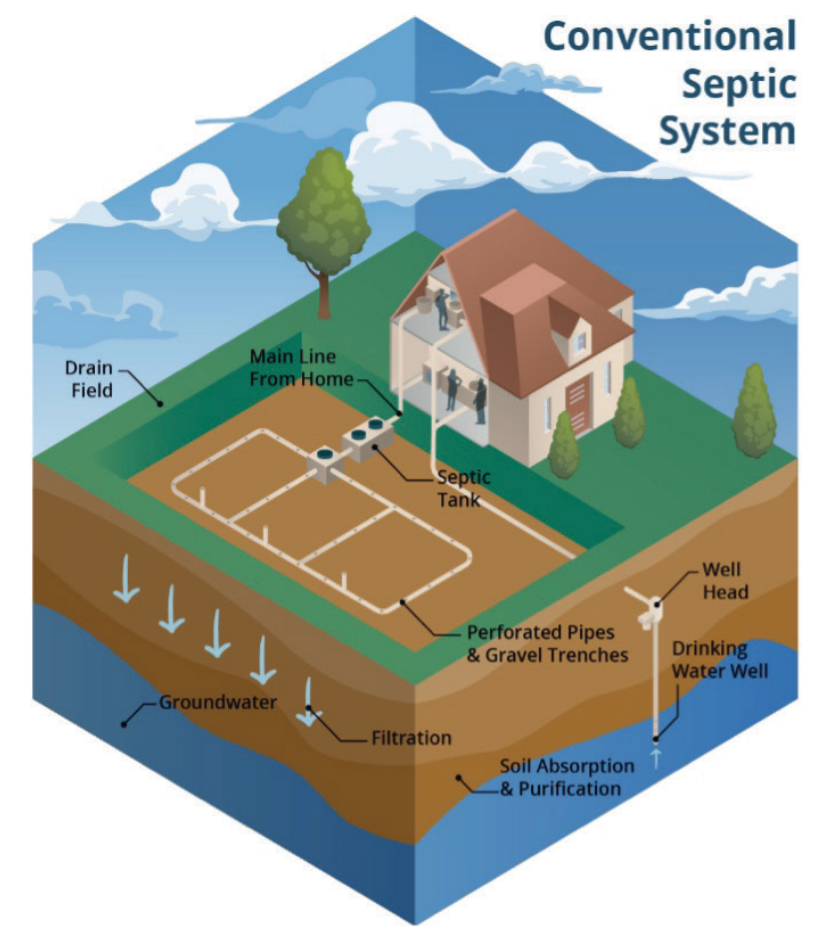

Figure 4. Conceptual drawing by Soil and Water Science Lab UF/IFAS GREC as featured in: Albertin, A. (2020). Septic systems do's and dont's after a flood.

Credits: USGS http://nwdistrict.ifas.ufl.edu/nat/category/water/

Unlike urban water systems, rural water systems are usually small-scale for a single residence. Septic systems slowly release wastewater back into the environment, where it will once again become part of the natural water cycle. Water undergoes a similar journey in both urban and rural systems, from the ground to a residence and back into the environment. 


\section{Released and Reused Water}

Reclaimed water is wastewater that has been treated and disinfected to meet appropriate standards. Often it is used to irrigate lawns and golf courses, mix with concrete, or cool power plants (USGS n.d.). Reclaimed water contains higher concentrations of nutrients like nitrogen and phosphorus than does drinking water (USGS n.d.). Using reclaimed water to irrigate lawns and golf courses can reduce the amount of fertilizer needed, because the water already has nutrients in it. Although reclaimed water is not directly consumed, it is used to supply water to outdoor water areas and wetlands, and it eventually makes its way into the aquifer. It also decreases our reliance on groundwater for irrigation and other uses. Treated wastewater that is not going to be reused for human purposes is released into both surface and groundwater. Surface waters include rivers and lakes.

\section{Conclusion}

As water continuously cycles throughout natural and human systems, it is imperative to understand how human actions above the surface have the potential to impact water quality and water availability. Ultimately, water quality and availability are vital to human health and quality of life, the economic well-being of humans, and the natural environment, all of which rely on water for survival. To learn more about how human activity can impact the quality and availability of the water in the Floridan Aquifer visit: https://edis.ifas.ufl.edu/entity/topic/floridan\%20aquifer.

\section{References}

Borisova, T., and T. Wade. 2017. Florida's Water Resources. FE757. Gainesville: University of Florida Institute of Food and Agricultural Sciences. https://edis.ifas.ufl.edu/fe757

United States Environmental Protection Agency (US EPA). 1998. How wastewater treatment works...The basics [PDF file]. Retrieved from https://www3.epa.gov/npdes/pubs/ bastre.pdf

Gainesville Regional Utilities (GRU). n.d. From ground to tap to ground [PDF file]. Retrieved from http://www.gru. com/Portals/0/OurCommunity/water-treatment-process. pdf

St. Johns River Water Management District. n.d. Florida's aquifers. Retrieved from https://www.sjrwmd.com/ water-supply/aquifer/
Toor, G. S., M. Lusk, and T. Obreza. 2011. Onsite Sewage Treatment and Disposal Systems: Overview.

SL347. Gainesville: University of Florida Institute of Food and Agricultural Sciences. https://edis.ifas.ufl.edu/ss549

USGS. n.d. Floridan Aquifer System Groundwater Availability Study. Retrieved from https://fl.water.usgs.gov/floridan/ intro.html

USGS. n.d. Reclaimed Wastewater. Retrieved from https:// www.usgs.gov/special-topic/water-science-school/science/ reclaimed-wastewater?qt-science_center_objects=0\#qtscience_center_objects 